\title{
Stability of the overworked slightly metamorphosed massif around mine working
}

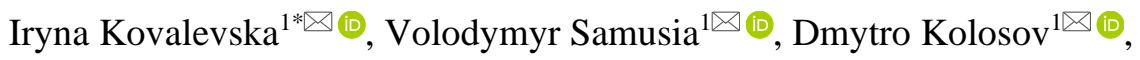 \\ Vasyl Snihur $^{2 \otimes}$, Tetiana Pysmenkova ${ }^{1 \otimes \text { (D) }}$ \\ ${ }^{1}$ Dnipro University of Technology, Dnipro, 49005, Ukraine \\ ${ }^{2}$ MM "Dniprovske”, PJSC "DTEK Pavlohradvuhillia”, Pavlohrad, 51400, Ukraine \\ *Corresponding author: e-mail kovalevska_i@yahoo.com, tel. +380503328585
}

\begin{abstract}
Purpose. The study of mechanisms of the overworked slightly metamorphosed massif stability around mine working using the example of laminal rocks in the Western Donbas (Ukraine).

Methods. The analysis of the overworking influence when planning mining operations on the underlying horizons has been made based on the studies of the stress-strain state on the overlying horizons. Attention was paid to the conditions of a slightly metamorphosed coal-bearing rock massif, which has specific mechanical properties and structural peculiarities. A computational experiment by the finite element method has been performed. The model adequacy and the calculation accuracy of the stress-strain state have been proved. The research results have been confirmed by a mine experiment.

Findings. The geomechanical model of the computational experiment has been substantiated, in which the real massif structure, factors of stratification, fracturing, and moisture saturation, which weaken the strength and deformation properties of the rocks, are reflected. The zones of uncontrolled collapse, hinged-block displacement, and smooth deflection of layers without discontinuity have been studied.

Originality. The patterns of the overworking influence on the state of mine workings in the laminal massif of soft rocks have been determined. Therewith, three areas of lithotypes discontinuity throughout a height of a parting have been identified and the stresses components parameters, as well as their compliance with real mining and geological conditions have been analysed.

Practical implications. It has been proved the absence of the overworking influence on the underlying mine workings state in a slightly metamorphosed massif. A comparative analysis with the mine experiment results has been made. The possibility of mining the protecting pillar reserves is shown, which will allow to extract additional coal without attracting significant material resources.
\end{abstract}

Keywords: rock massif, geomechanical factors, overworking, stress-strain state, support

\section{Introduction}

In the world practice of the coal seam series development, the influence of previous periods of conducting mining operations should be constantly taken into account [1]-[4]. Under the conditions of a more widespread downward order of mining the coal seams in the series, when planning mining operations on the underlying horizons, it is necessary to take into account the mining and geological situation that has developed during the reserves extraction on overlying horizons [5]-[7]. This situation is conditioned by various miningengineering factors influence and is quite individual in each specific case, for example:

- overworking of the mine field area of the underlying coal seam occurred in a relatively early period of time during which the areas of rock pressure anomalies (the so-called bearing pressure and unloading zones) have changed their parameters due to the rheological phenomena of creep deformations and stresses relaxation; some consolidation occurred of partially and completely earlier destroyed mine rocks [8];

- joint mining of two or three coal seams is applied with some extraction advance of the overlying seams relative to the underlying ones; the time interval for overworking is quite limited, therefore, the rheological processes of creep deformations and stresses relaxation (in the anomalous rock pressure zones) are in the stage of active development, especially in the conditions of a slightly metamorphosed mine rock massif; here it is very important to substantiate the safe mining-engineering and technological parameters of joint seams mining [9]-[11];

- in order to implement a strategy for a more complete coal extraction, protecting pillars on overlying horizons are 
developed (partially or completely) or engineering decisions are substantiated to limit their sizes on the operating (for the current period of time) main working horizons;

- other mining-and-geological and mining-engineering situations are possible using both traditional stoping equipment and manless coal winning [12]-[17].

The above directions of studying the overworking influence on the coal-bearing massif stability represent only a part of the geomechanics tasks for substantiation of mining operations parameters under the conditions of their mutual influence on different horizons of performing the stope extraction. Such tasks relevance emphasizes an increased attention of scientists and practitioners to the study of mine rock massif behaviour under the conditions of its overworking [18]-[20].

The variety of existing works in the sphere of studying the overworked massif state convincingly proves this problem relevance both at present time and for a long-term perspective of mining development [21]. Moreover, the solution of such tasks for the conditions of a slightly metamorphosed coal-bearing rock massif acquires a particular importance due to the lithotypes specific mechanical properties and the coal-bearing massif structure typical for the West Donbas field [22]-[26].

\section{Methods}

In the Western Donbas mines, many engineering decisions are caused by the necessity to consider overworking of the soft rocks laminal massif for efficient conducting mining operations on underlying horizons and, in particular, to assess the conditions for maintaining mine workings and developing appropriate measures to ensure their trouble-free operation. One of such relevant mining-engineering tasks arose in M.I. Stashkova Mine in the Western Donbas, the essence of which is to substantiate the expediency of mining the seam $C_{6}$ reserves in the zone of the protecting pillar of the steep-dipping ventilation crosscut No. 1 (SVC No. 1) of the seam $C_{5}+C_{5}{ }^{u}$, provided that its operational state is reliably maintained. A successful solution to this task is to substantiate the absence of influence of mining operations conducted along the seam $C_{6}$ on the rock pressure manifestations in the SVC No. 1 of the seam $C_{5}$.

The evidence base is the parameters of the parting rocks state, which was formed by the seams $C_{6}$ and $C_{5}+C_{5}{ }^{u}$; their determination and analysis is the main purpose of research. It was implemented by means of calculating and analysing the stress-strain state (SSS) of parting rocks using the widely tested finite element method (FEM) and modelling experience [27]-[29]. of similar geomechanical systems for the specific Western Donbas conditions.

The substantiation of geometric, mechanical and force parameters of the geomechanical model is designed to provide a sufficient level of its adequacy to real conditions. This enables to obtain reliable results of calculating the SSS components of parting, based on which the conclusions are drawn about the degree of overworking influence on the SVC No. 1 stability of the seam $C_{5}$.

First of all, let us consider the geometric model parameters, according to which it is necessary to observe a number of key conditions.

Firstly, the model height should include all objects of research that are of interest to us, taking into account the rock pressure anomalies propagated from them to a certain height in the roof of the seam $C_{6}$ and in the soil of the seam $C_{5}+C_{5}{ }^{u}$. Thus, during the stope extraction of coal seam in the Western Donbas conditions, the frontal bearing pressure, as a rule, is attenuated in the zone to a height of up to 12-15 $\mathrm{m}$. This is conditioned by the weak strength properties of lithotypes and their lamination, at which the rock cantilevers are regularly collapsed (above the mined-out space) with an overhang of a short length. Under such conditions, the frontal bearing pressure zone is sufficiently limited in height of propagation. Nevertheless, with a certain safety factor of the obtained results, we have included into the model thick argillite and siltstone, which occur in the roof of the seam $C_{6}{ }^{1}$; as a result, the total thickness of the seam $C_{6}$ roof rocks is $23.3 \mathrm{~m}$ in the model. Such a model height reserve above the seam $C_{6}$ also plays a positive role in removing the so-called "edge effects" from applying a geostatic pressure $\gamma H$ (here $\gamma$ is the weight-average unit specific gravity of the rocks in the occurrence depth $H$ ) at the upper boundary of a model.

Secondly, a thickness of a parting of the seams $C_{6}$ and $C_{5}+C_{5}{ }^{u}$, which varies within the range of $26-28 \mathrm{~m}$, is included as a component in the height of the model.

Thirdly, in the seam $C_{5}+C_{5}{ }^{u}$ bottom, the SVC No. 1 of the seam $C_{5}$ is located, the very existence of which forms the rock pressure anomalies in the form of an unloading area under the mine working and the areas of increased rock pressure in its sides. The unloading area of up to 6-8 $\mathrm{m}$ is usually the most propagated to the mine working bottom. Given the mine working height and possible fluctuations in the seam $C_{5}+C_{5}{ }^{u}$ hypsometry, a modelling depth of $15.4 \mathrm{~m}$ from the coal seam has been adopted. This depth reserve is positive in terms of compensation for "edge effects" in the area of bearing the model at its lower boundary.

Thus, the total model height was $66.7 \mathrm{~m}$, which ensured the objectivity of modelling of all the geomechanical processes under study.

Then, the minimum sufficient width (coordinate $X$ ) of the geomechanical model has been substantiated. On the coordinate axis $X$ along the extraction site of the seam $C_{6}$, there are zones of frontal bearing pressure and unloading, which have a maximum depth of development in the longwall face area, and as they recede from it (on the rise-dip of the seam) they either disappear or are stabilized at a certain level. This distance for the Western Donbas conditions is usually 40-60 m from the stope face and its maximum value is used when constructing the geomechanical model. As a result, given the width of the longwall face and some length reserve for the edge effects action at the lateral model boundaries, its length $X=150 \mathrm{~m}$ is adopted, which will provide the necessary adequacy and reliability of the massif SSS calculation results.

The last dimension of the geomechanical model represents its thickness in the coordinate $Z$, which has a direction parallel to the stope face plane along the seam $C_{6}$ and perpendicular to the vertical axis of the SVC No. 1 of the seam $C_{5}$. The importance of dimension $Z$ is conditioned by location in the seam $C_{5}+C_{5}{ }^{u}$ bottom of mine working, the existence of which, in itself, has a specific influence on the SSS of adjacent rocks. The minimum sufficient dimensions along the coordinate $Z$ have been selected from the condition that there are no perturbations in the SSS components at the lateral boundaries of the model, which could be caused by the SVC No. 1 of the seam $C_{5}$ influence. For this reason, the main geomechanical model thickness has been adopted as $Z=25 \mathrm{~m}$. 
Within the substantiated model dimensions, according to the mining-and-geological predicting data, a real structure of the studied coal-bearing rock massif area has been constructed, which is reflected in Figure 1.

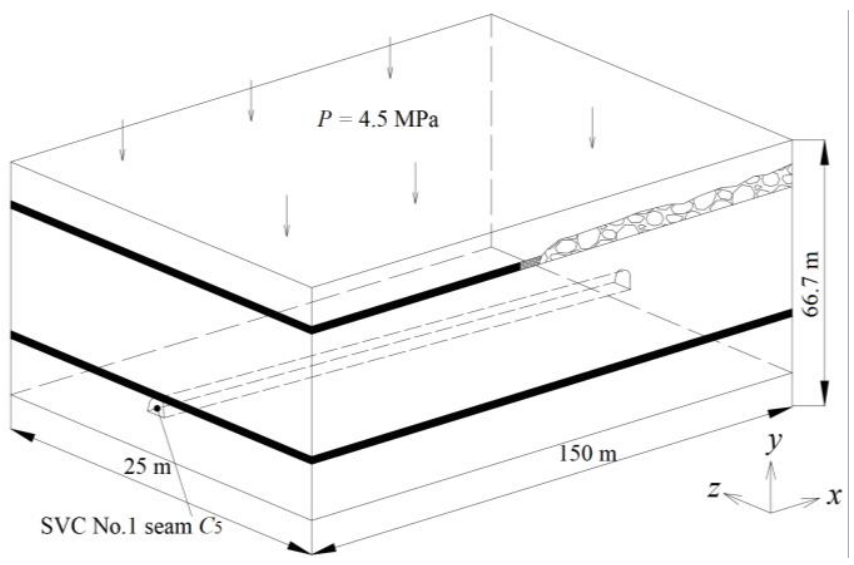

Figure 1. General view of the geomechanical model of overworking of the SVC No. 1 of the seam $C_{5}$

The geometry of the powered support sections (coal extraction complex on the seam $C_{6}$ ) is idealized in the form of a prism with appropriate dimensions, and the contour of the SVC No. 1 of the seam $C_{5}$ reflects the real geometric parameters of mine working.

Further on, the substantiation is presented for the mechanical (strength and deformation) parameters of elements that constitute the model. To calculate the SSS of the geomechanical system, each lithotype of the coal-bearing massif was assigned by a set of mechanical characteristics from the database of the Geological Survey of mines, studies of the M.S. Polyakov Institute of Geotechnical Mechanics under the NAS of Ukraine (IGTM of the NAS of Ukraine) and works [30]-[32], which are devoted to the study of the Western Donbas rock properties.

These data (within the studied area of the coal-bearing massif) has been analysed taking into account the action of factors weakening the rock: stratification, fracturing and moisture saturation. The analysis results are presented in Table 1 through the values of each lithotype mechanical characteristics, which are included in the SSS calculation programme.

Behind the longwall face (along the seam $C_{6}$ ), a zone of uncontrolled collapse is formed, composed of the compacted argillite fragments of the immediate roof. Its parameters are substantiated on the basis of research [28], [33]-[36]: thickness is $2.8 \mathrm{~m}$; compressive resistance is $2 \mathrm{MPa}$, tensile strength is $0.05 \mathrm{MPa}$; deformation modulus is $50 \mathrm{MPa}$; shear modulus is $17 \mathrm{MPa}$.

Table 1. The mine rocks mechanical characteristics, adopted for modelling, in accordance with the geologic cross-section along the SVC No. 1 of the seam $C_{5}$

\begin{tabular}{|c|c|c|c|c|c|}
\hline Mine rock type & Thickness, m & $\begin{array}{c}\text { Compressive } \\
\text { resistance, } \mathrm{MPa}\end{array}$ & $\begin{array}{c}\text { Tensile } \\
\text { strength, } \mathrm{MPa}\end{array}$ & $\begin{array}{l}\text { Deformation } \\
\text { modulus, } \mathrm{MPa}\end{array}$ & $\begin{array}{c}\text { Shear } \\
\text { modulus, MPa }\end{array}$ \\
\hline Siltstone & 7.3 & 25.9 & 1.7 & $1.1 \cdot 10^{4}$ & $4.2 \cdot 10^{3}$ \\
\hline Argillite & 4.8 & 20.6 & 2.3 & $0.6 \cdot 10^{4}$ & $2.3 \cdot 10^{3}$ \\
\hline Coal of the seam $C_{6}{ }^{1}$ & 0.8 & 30.7 & 1.2 & $0.4 \cdot 10^{4}$ & $1.5 \cdot 10^{3}$ \\
\hline Argillite & 6.8 & 3.1 & 0.2 & $0.1 \cdot 10^{4}$ & $0.4 \cdot 10^{3}$ \\
\hline Sandstone & 1.2 & 6.7 & 0.8 & $0.5 \cdot 10^{4}$ & $1.9 \cdot 10^{3}$ \\
\hline Argillite & 2.4 & 3.1 & 0.2 & $0.1 \cdot 10^{4}$ & $0.4 \cdot 10^{3}$ \\
\hline Coal of the seam $C_{6}$ & 0.9 & 30.7 & 1.6 & $0.4 \cdot 10^{4}$ & $1.5 \cdot 10^{3}$ \\
\hline Argillite & 3.5 & 3.6 & 0.3 & $0.15 \cdot 10^{4}$ & $0.6 \cdot 10^{3}$ \\
\hline Coal & 0.2 & 30.7 & 1.6 & $0.4 \cdot 10^{4}$ & $1.5 \cdot 10^{3}$ \\
\hline Argillite & 0.8 & 3.6 & 0.3 & $0.15 \cdot 10^{4}$ & $0.6 \cdot 10^{3}$ \\
\hline Siltstone & 2.0 & 13.2 & 1.2 & $0.6 \cdot 10^{4}$ & $2.3 \cdot 10^{3}$ \\
\hline Argillite & 5.8 & 12.9 & 1.6 & $0.4 \cdot 10^{4}$ & $1.5 \cdot 10^{3}$ \\
\hline Sandstone & 1.6 & 17.4 & 2.1 & $1.2 \cdot 10^{4}$ & $4.6 \cdot 10^{3}$ \\
\hline Argillite & 2.6 & 2.7 & 0.1 & $0.1 \cdot 10^{4}$ & $0.4 \cdot 10^{3}$ \\
\hline Coal of the seam $C_{5}{ }^{1}$ & 0.4 & 30.7 & 1.6 & $0.4 \cdot 10^{4}$ & $1.5 \cdot 10^{3}$ \\
\hline Argillite & 0.6 & 2.7 & 0.1 & $0.1 \cdot 10^{4}$ & $0.4 \cdot 10^{3}$ \\
\hline Sandstone & 2.0 & 17.4 & 2.1 & $1.2 \cdot 10^{4}$ & $4.6 \cdot 10^{3}$ \\
\hline Siltstone & 5.2 & 3.2 & 0.1 & $0.2 \cdot 10^{4}$ & $0.8 \cdot 10^{3}$ \\
\hline Argillite & 2.5 & 12.9 & 1.6 & $0.4 \cdot 10^{4}$ & $1.5 \cdot 10^{3}$ \\
\hline Coal of the seam $C_{5}+C_{5}^{u}$ & 1.1 & 30.1 & 1.1 & $0.4 \cdot 10^{4}$ & $1.5 \cdot 10^{3}$ \\
\hline Argillite & 2.2 & 2.7 & 0.1 & $0.1 \cdot 10^{4}$ & $0.4 \cdot 10^{3}$ \\
\hline Siltstone & 2.4 & 13.2 & 1.2 & $0.6 \cdot 10^{4}$ & $2.3 \cdot 10^{3}$ \\
\hline Coal of the seam $C_{4}{ }^{3}$ & 0.3 & 30.1 & 1.1 & $0.4 \cdot 10^{4}$ & $1.5 \cdot 10^{3}$ \\
\hline Siltstone & 4.5 & 6.2 & 0.5 & $0.3 \cdot 10^{4}$ & $1.2 \cdot 10^{3}$ \\
\hline Coal of the seam $C_{4}^{2}+C_{4}^{2 u}$ & 0.2 & 30.1 & 1.1 & $0.4 \cdot 10^{4}$ & $1.5 \cdot 10^{3}$ \\
\hline Siltstone & 5.8 & 24.6 & 1.7 & $1.1 \cdot 10^{4}$ & $4.2 \cdot 10^{3}$ \\
\hline
\end{tabular}

The powered support of the stope face along the seam $C_{6}$ is simulated in the geomechanical model, reflecting the actual deformation-strength characteristics of the section. Thus, it was taken into account that most of the used coal extraction complexes develop a maximum resistance of about $500 \mathrm{kPa}$; therewith, the lowering of the section prop stays (when the safety valves actuate) usually does not exceed $100 \mathrm{~mm}$ in the stable operation mode of the complex, which does not allow its landing on a "rigid base". Taking into consideration the extraction thickness value of the seam $C_{6}$, the relative yielding deformation of the section simulator will be about $10 \%$, and its deformation modulus will be $5 \mathrm{MPa}$; then the second 
deformation characteristic of the simulator - the shear modulus - is accepted to be the value of $1.9 \mathrm{MPa}$ in accordance with the classical provisions [37] of the deformable solid mechanics. The strength characteristic of the powered support section simulator is one parameter - the yield limit of steel - in view of the equality of the compressive resistance and tensile strength of this material [38]; for structural steels with a certain stability factor, the estimated yield limit is accepted to be $300 \mathrm{MPa}$ according to [39], [40].

The frame support of the SVC No. 1 of the seam $C_{5}$ is not modelled for the following reasons. On one hand, some elements of support (for example, yielding joists, backing plates for frame prop stays) and the cross section of the cap board and frame prop stays from SCP-27 have dimensions that differ by one or two orders of magnitude from those for most of the geomechanical model lithotypes. The experience gained in calculating such multiscale geomechanical systems indicates not only the emergence of significant difficulties in adequate reflection of fastening structures, but also a sharp decrease in the computational experiment reliability due to the regular "failures" in the calculation process. On the other hand, it is well known [41], [42] that the frame support reaction is at least one and a half orders of magnitude less than the level of stresses in the rock massif, caused by the geostatic rock pressure action. Therefore, usually, the influence of the frame repulse reaction extends only to a limited volume of border rocks, which is incommensurably small in relation to the dimensions of the studied parting, to say nothing of dimensions of the entire geomechanical model. As a result, a number of geotechnical engineers estimate the error of neglecting the support influence by the value up to several percent, which is quite acceptable for mining-engineering calculations.

The last stage in constructing a geomechanical model is to substantiate its strength parameters in accordance with the mining-geological and mining-engineering conditions under study.

At the upper model boundary, a geostatic vertical pressure of $P=4.5 \mathrm{MPa}$ is applied, corresponding to an average depth of about $180 \mathrm{~m}$, at which the protecting pillar of the seam $C_{6}$ will be mined out. The lower boundary is fixed rigidly in view of existing recommendations for the geomechanical models construction. The condition of "symmetry" has been set on all lateral faces of the model, which means the absence of their displacement, since a coal-bearing rock massif with the same mechanical properties is also located around the computational scheme. To implement the condition of "symmetry", it is necessary to use the Poisson's ratio $\mu$, the values of which have been chosen according to the research results of the IGTM of the NAS of Ukraine: argillite $\mu=0.35$; siltstone $-\mu=0.25$; sandstone $-\mu=0.40$; coal $\mu=0.30$. The indicated values of the Poisson's ratio automatically determine (for each lithotype) the coefficient of side thrust and the corresponding lateral load on the separate sections of the model lateral faces. According to the described methodology, all external (relative to the model) active and reactive loads were determined.

The efforts inside the geomechanical model include the reaction of powered support and the force interaction of adjacent lithotypes with each other. The reaction of the powered support is assigned by a variable depending on the value of lowering the immediate roof rocks in the longwall face and the deformation characteristics of the section simulator; its reaction is calculated automatically. The force inter- action of adjacent lithotypes in the massif structure is determined solely by friction forces, since the horizontal shifts of layers, considering very weak coherency between them, disrupt adhesion along the bedding planes.

Thus, all the necessary substantiations and constructions of the geomechanical model have been completed. It successfully passed the testing cycle for consistency with existing concepts about the processes of coal-bearing stratum displacement.

\section{Results and discussion}

As a result of the computational experiment performance, the distribution fields of all stresses components have been determined, and the main attention in the SSS analysis was paid to the three most informative components: vertical $\sigma_{y}$, horizontal $\sigma_{x}$ in the direction to the rise-dip of the coal seams and stresses intensity $\sigma$, according to which the mine rock state (prelimiting, limiting, superlimiting) is assessed.

In the rocks of parting of the seams $C_{6}$ and $C_{5}+\mathrm{C}_{5}{ }^{u}$, a number of peculiarities of the vertical stresses $\sigma_{y}$ distribution in the zone of frontal bearing pressure is observed during the excavation of protecting pillar of the seam $C_{6}$ (Fig. 2).

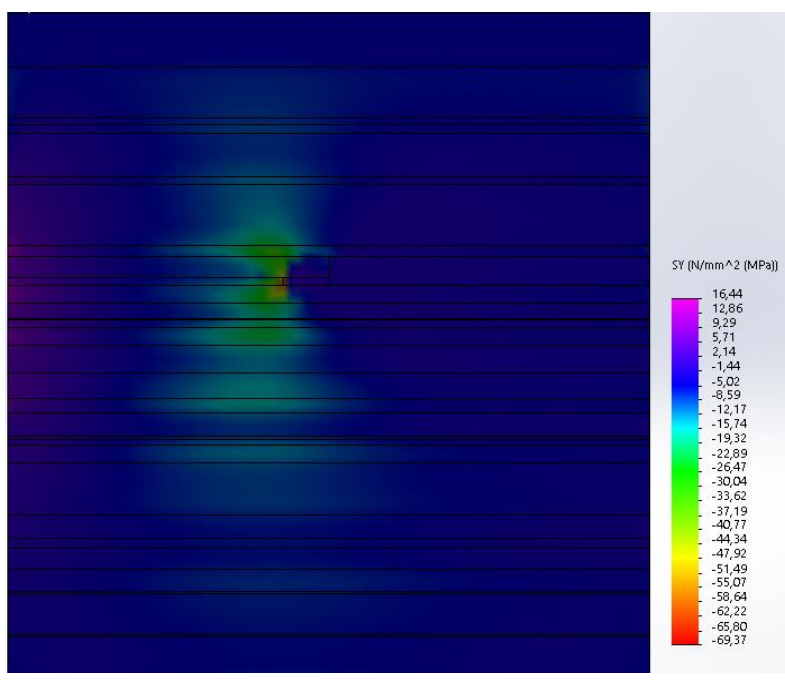

Figure 2. Curve of vertical stresses $\sigma_{y}$ in the coal-bearing massif

Maximum concentrations $\sigma_{y}$ of the $K_{y}=\sigma_{y} / \gamma H=10.2-12.2$ level are observed near the stope face at a distance of $0.8-0.9 \mathrm{~m}$ to the rise and $1.0-1.3 \mathrm{~m}$ to the deep of the immediate bottom. Further on, to the argillite thickness and with removal (from the face) to the rise of the seam, the concentrations $\sigma_{y}$ decrease, but destructive values remain, given the weak compressive resistance of argillite $\left(\sigma_{\text {compr }}=3.6 \mathrm{MPa}\right)$. This is conditioned by its moisture saturation from the waterflooded seam $C_{6}$ and the underlying coal interlayer in the argillite bottom. Thus, the area with an indicator $\sigma_{y} / \sigma_{\text {compr }}=6.4-9.2$ extends to the rise up to $4.0 \mathrm{~m}$ and by the entire argillite thickness; the area with an indicator $\sigma_{y} / \sigma_{\text {compr }}=2.4-4.5$ occupies a section to the rise of the seam up to $7.8 \mathrm{~m}$ long. The noted data unambiguously indicate weakening (according to the factor of $\sigma_{y}$ action) of the argillite in the immediate bottom to its entire thickness of $3.5 \mathrm{~m}$.

The nearest two layers of the main bottom are of low thickness (coal interlayer $-0.2 \mathrm{~m}$ and argillite $-0.8 \mathrm{~m}$ ) and only this factor gives reason to claim about their weakening under the influence of surrounding rocks deformations. The coal interlayer is quite hard $\left(\sigma_{\text {compr }}=30.7 \mathrm{MPa}\right)$, but under 
the influence of alternating-sign flexure strains, it is divided by vertical fractures into small fragments. A thin argillite layer is exposed to moisture saturation and loses its compressive resistance up to $\sigma_{\text {compr }}=3.6 \mathrm{MPa}$. At the same time, vertical stresses $\sigma_{y}$ of much higher value are acting near the longwall face: in the area up to $5.0 \mathrm{~m}$ long to the rise $\sigma_{y}=16-23 \mathrm{MPa}$ are acting, and at a length of up to $11 \mathrm{~m}-$ $\sigma_{y}=8-15 \mathrm{MPa}$ exceed $\sigma_{\text {compr }}$ by several times, which leads to the process of argillite weakening.

Below a siltstone occurs, which in a naturally moist state has a compressive resistance of $\sigma_{\text {compr }}=13.2 \mathrm{MPa}$, but weakening concentrations of $\sigma_{y}>14-15 \mathrm{MPa}$ are propagated throughout its thickness and to a length of $10 \mathrm{~m}$ to the rise.

The fourth layer of the main bottom is represented by thick argillite with a compressive resistance of $\sigma_{\text {compr }}=12.9 \mathrm{MPa}$. Middle part of its thickness already maintains continuity according to the factor of the vertical stresses $\left(\sigma_{y}<\sigma_{\text {compr }}\right)$ action, but weakening still occurs in the upper and lower parts of the argillite thickness:

- at the top of a lithotype to a depth of 1.3-1.5 $\mathrm{m}$ and to the rise - to a length of 9-10 m;

- at the bottom of a lithotype to a height of 1.8-2.3 $\mathrm{m}$ and to the rise - to a length of $12-13 \mathrm{~m}$.

Thus, in the zone of the frontal bearing pressure, the first area of weakened bottom rocks reaches a depth of $8.0 \mathrm{~m}$ and is propagated to the rise of up to $13.0 \mathrm{~m}$.

The second weakening area, occurring below, begins with the already noted part of the thick argillite weakening (1.8-2.3 $\mathrm{m} \mathrm{high)} \mathrm{and} \mathrm{extends} \mathrm{deep} \mathrm{into} \mathrm{the} \mathrm{parting} \mathrm{as} \mathrm{follows.}$ In soft water-flooded sandstone $\left(\sigma_{\text {compr }}=17.4 \mathrm{MPa}\right)$, vertical stresses $\sigma_{y}=15.7-19.3 \mathrm{MPa}$ are propagated to most part $(1.2-1.3 \mathrm{~m})$ of its thickness to $1.6 \mathrm{~m}$ and form the limiting state of sandstone, which propagates to the rise up to 8.0-9.5 m. According to the factor of $\sigma_{y}$ action, this area of a parting is on the verge of weakening, but the lower sandstone band maintains stability.

Argillite is located under water-flooded sandstone, which in a water-saturated state reduces its compressive resistance to $\sigma_{\text {compr }}=2.7 \mathrm{MPa}$. $\sigma_{y}=5$ to $9 \mathrm{MPa}$ act to about half of the argillite thickness, which leads to its partial weakening; the lower part of the argillite thickness maintains continuity according to the factor of $\sigma_{y}$ action.

Thus, the described second area of a parting can be characterized as that exposed to partial weakening, but most its part is still in the limiting state. Hence, when removing the increased rock pressure (when passing into the unloading zone behind the longwall face), this area with a depth of 5-6 $\mathrm{m}$ and a width of 13-15 $\mathrm{m}$ will be in a relatively stable state.

The third characteristic area of a parting includes a water-flooded coal seam $C_{5}{ }^{1}$, low-thickness argillite in a watersaturated state, water-flooded sandstone with a thickness of $2.0 \mathrm{~m}$ and partially water-saturated (upper bands) siltstone with a thickness of $5.2 \mathrm{~m}$; the listed lithotypes behave differently according to the factor of $\sigma_{y}$ action. Thus, the seam $C_{5}{ }^{1}$ is in a stable state, since for it the indicator is $\sigma_{y} / \sigma_{\text {compr }}=0.13-0.21$. On the contrary, the underlying watersaturated argillite with a low thickness $(0.6 \mathrm{~m})$ has a compressive resistance of only $\sigma_{c o m p r}=2.7 \mathrm{MPa}$, and the acting $\sigma_{y}=9-13 \mathrm{MPa}$; it is obvious that argillite will be weakened in all its thickness to a width (to the rise) of up to $15-17 \mathrm{~m}$. The underlying water-flooded sandstone, although it experiences increased $\sigma_{y}=12-14 \mathrm{MPa}$, but its compressive resistance $\sigma_{\text {compr }}=17.4 \mathrm{MPa}$ is still higher, which allows to predict a stable state. Under the water-flooded sandstone a thick siltstone is located, the upper part of which is water-saturated with a decrease in compressive resistance to $\sigma_{\text {compr }}=3.2 \mathrm{MPa}$. Therefore, the low concentrations $\sigma_{y}=6-9 \mathrm{MPa}$ weaken the upper siltstone bands to a depth of 1.0-1.5 m, and most of its thickness is in a stable state.

In general, the third area of partially weakened lithotypes (4.0-4.5 $\mathrm{m}$ deep and 15.0-17.0 $\mathrm{m}$ wide) characterizes the attenuation in the frontal bearing pressure zone.

The lithotypes located below (argillite of the immediate roof, seam $C_{5}+\mathrm{C}_{5}{ }^{u}$, argillite of the immediate bottom and the main bottom rocks) to the studied depth of $19.0 \mathrm{~m}$ resist to the geostatic vertical pressure of the virgin massif. Therefore, it is possible to make the main conclusion: mining the protecting pillar of the seam $C_{6}$ does not change the vertical stresses $\sigma_{y}$ field in the rock massif surrounding the SVC No. 1 of the seam $C_{5}$.

As an indirect verification of the formulated conclusion, the calculations of a parting stability were made according to the methodology [27], which have confirmed the fact of limited influence of the stope works in the seam $C_{6}$ at a depth of $63-65 \%$ of parting thickness. That is, the lower third of a parting is in the initial geostatic state of the virgin massif.

The patterns of horizontal stresses $\sigma_{x}$ distribution most clearly reflect the lithotypes flexure strains of the studied coalbearing stratum along the length $X$ of the mined-out protecting pillar of the seam $C_{6}$. It is reasonable to expect that the most intense bending of the rock layers is observed in the roof and bottom of the seam $C_{6}$ in the area of conducting stope works, which is recorded on the curve $\sigma_{x}$ (Fig. 3). This curve was obtained from the computational experiment results.

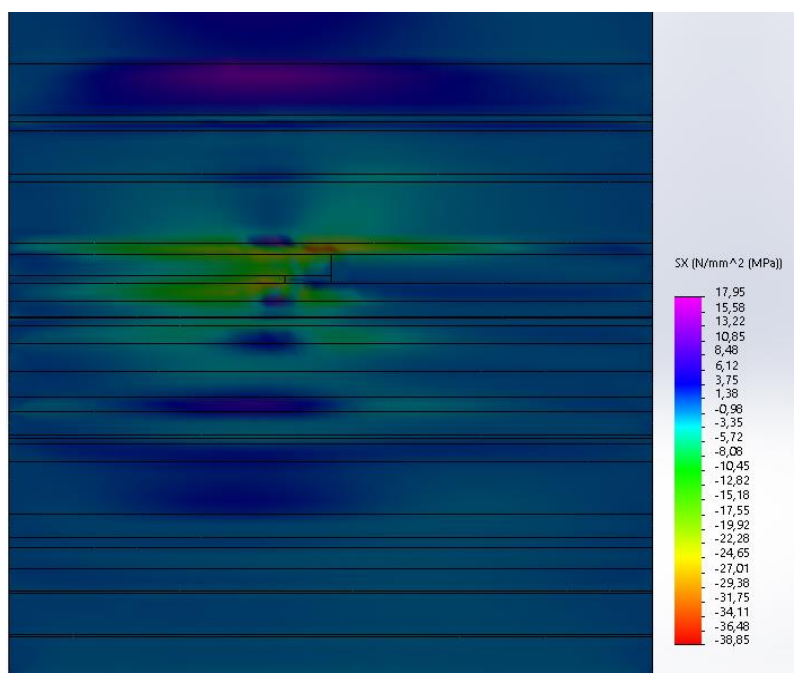

Figure 3. Curve of horizontal stresses $\sigma_{x}$ in the coal-bearing massif

In the immediate bottom of the seam $C_{6}$, two areas of increased $\sigma_{x}$ are formed: the first, up to the stope face, extending to the rise up to $20-22 \mathrm{~m}$, where it is mainly $\sigma_{x}=6-15 \mathrm{MPa}$, and in the upper part of argillite (up to $4.0 \mathrm{~m}$ wide) adjacent to the longwall face, up to $\sigma_{x}=22-30 \mathrm{MPa}$; the second area extends to the rise up to 7-8 $\mathrm{m}$ with $\sigma_{x}=6-12 \mathrm{MPa}$ and occupies a position under the working space of the longwall face and behind it. The argillite itself is located between two water-flooded lithotypes (a seam $C_{6}$ above and a coal interlayer with a thickness of $0.2 \mathrm{~m}$ below) and, according to the Geological Survey of mines, it is prone to soaking and to a significant loss of strength of up to $\sigma_{\text {compr }}=3.6 \mathrm{MPa}$. Comparing 
this value $\sigma_{\text {compr }}$ and the level of acting horizontal stresses, it is possible to quite reasonably predict the stability loss of the immediate bottom by the entire argillite thickness.

The underlying nameless coal interlayer, even in a waterflooded state, has a compressive resistance many times higher than the acting $\sigma_{x}$. But, a very low thickness $(0.2 \mathrm{~m})$ of the interlayer does not allow it to maintain continuity under the influence of active flexure strains in the zone of frontal bearing pressure.

A similar conclusion refers to low-thickness argillite $(0.8 \mathrm{~m})$, which occurs under a water-flooded coal interlayer and for this reason is in a water-saturated state. Its compressive resistance is by 1.6-2.3 times lower than the concentrations $\sigma_{x}$ arising in the area ahead of the longwall face and under it, extending up to $15-16 \mathrm{~m}$ to the rise. Therefore, this lithotype is predicted to be weakened according to the factor of horizontal stresses $\sigma_{x}$ action.

The next lithotype of the main bottom - siltstone with a thickness of $2.0 \mathrm{~m}$ is in a naturally moist state with a compressive resistance of $\sigma_{\text {compr }}=13.2 \mathrm{MPa}$. Its curve $\sigma_{x}$ is characterized by three areas to the rise:

- the first begins at a distance of 5-7 $\mathrm{m}$ to the longwall face, takes a width of 9-12 $\mathrm{m}$ and is characterized by increased compressive stresses $\sigma_{x}=5-8 \mathrm{MPa}$, which are not able to weaken the rock;

- the second area of increased compressive stresses $\sigma_{x}=5-10 \mathrm{MPa}$ is located under the longwall face and behind it under the mined-out space with a total width of up to 8-10 $\mathrm{m}$; here, the rock is also resistant to action of compressive stresses $\sigma_{x}$;

- the third area is located between the first two, has a width of up to 5-6 $\mathrm{m}$ and is characterized by the action of tensile stresses $\sigma_{x}=2-8 \mathrm{MPa}$, which exceed the tensile strength of siltstone ( $\left.\sigma_{p}=1.2 \mathrm{MPa}\right)$ even without taking into account the weakening effect of its fracturing; therefore, it is in the very third area, the siltstone discontinuity is predicted by means of its separation into blocks by tension cracks.

Summing up the state of the indicated lithotypes of the seam $C_{6}$ bottom, it is possible to predict their weakening (in the frontal bearing pressure zone) to a total depth of up to $7.5 \mathrm{~m}$; therewith, some local areas (within the marked rock volume) maintain continuity.

A similar holistic state is predicted for thick argillite:

- insignificant concentrations of compressive stresses $\sigma_{x}=3-5 \mathrm{MPa}$ are many times lower than its compressive resistance $\sigma_{\text {compr }}=12.9 \mathrm{MPa}$;

- the exception is two local areas of argillite in the roof (up to $0.7 \mathrm{~m}$ high) and bottom (up to $0.5 \mathrm{~m}$ high), where tensile stresses $\sigma_{x}$ exceed its tear resistance $\sigma_{p}=1.6 \mathrm{MPa}$;

- the rest argillite thickness with a height of up to $4.6 \mathrm{~m}$ is in a stable state.

Further on, to the deep of the massif, there are two more areas where the weakening of lithotypes occurs by their separation into blocks under the action of horizontal tensile stresses $\sigma_{x}$.

The first area is located by the entire sandstone thickness and is propagated to the rise up to $18-22 \mathrm{~m}$. Here, the tensile stresses $\sigma_{x}=2-6 \mathrm{MPa}$ either correspond to its tensile strength $\sigma_{p}=2.1 \mathrm{MPa}$ or surpass it.

Argillite with a thickness of $2.6 \mathrm{~m}$, a coal seam $C_{5}{ }^{1}$ with a thickness of $0.4 \mathrm{~m}$ and argillite of its immediate bottom with a thickness of $0.6 \mathrm{~m}$ are located below, where the value $\sigma_{x}$ approximately corresponds to the state of the virgin massif and this rock volume with a total thickness of $3.6 \mathrm{~m}$ is characterized as holistic and stable.

The second area of rocks, which are divided into blocks under the action of tensile stresses $\sigma_{x}$ is sandstone with a thickness of $2.0 \mathrm{~m}$ and siltstone with a thickness of $5.2 \mathrm{~m}$. Here, a discontinuity is predicted at a distance to the rise up to $17-20 \mathrm{~m}$. On the other hand, a thrust-block system with such a thickness has a significant load-bearing capacity and can withstand not only its own weight, but also some rock pressure from the overlying lithotypes. From this point of view, sandstone and siltstone can be attributed to the category of stable rocks that do not create additional rock pressure on the underlying lithotypes.

The above said not only affects the state of underlying lithotypes, but also serves as evidence that a distribution of $\sigma_{x}$, close to the virgin massif parameters, indicates that there is no frontal bearing pressure influence during mining the seam $C_{6}$ on the state of rocks near the seam $C_{5}+C_{5}{ }^{u}$. These rocks include argillite of the immediate roof, the coal seam $C_{5}+C_{5}{ }^{u}$ itself, argillite of the immediate bottom, siltstones and coal seams $C_{4}{ }^{3}$ and $C_{4}{ }^{2}+C_{4}{ }^{2 u}$; the total lithotypes thickness (without signs of the overworking influence) is $19.0 \mathrm{~m}$.

Thus, it has been determined that, according to the factor of horizontal stresses $\sigma_{x}$ action, the influence of stope works along the seam $C_{6}$ on the state of the massif around the SVC No. 1 of the seam $C_{5}$ is completely absent.

The parameter generalizing the SSS of the coal-bearing massif in terms of its state (prelimiting, limiting, and superlimiting) is the stresses intensity $\sigma$, the curve of which is represented in Figure 4.

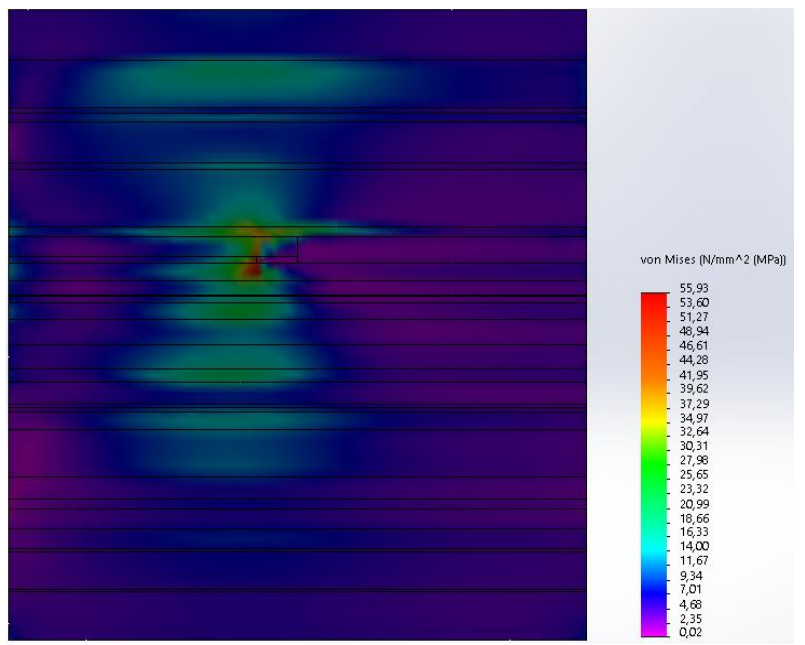

Figure 4. Stresses intensity $\sigma$ distribution in the coal-bearing massif

The immediate bottom of the seam $C_{6}$ is represented by argillite with a thickness of $3.5 \mathrm{~m}$, which is located between two water-flooded lithotypes: seam $C_{6}$ and coal interlayer with a thickness of $0.2 \mathrm{~m}$. For the above reasons and with account of the natural fracturing of medium intensity, the argillite moisture saturation is predicted by its entire thickness, which leads to a decrease in compressive resistance beyond $\sigma_{\text {compr }}=3.6 \mathrm{MPa}$. At the same time, the curve of $\sigma$ distribution in argillite has the following indicators:

$-\sigma=9-15 \mathrm{MPa}$ in the area along the strike up to $12-14 \mathrm{~m}$;

$-\sigma=17-33 \mathrm{MPa}$ in the area up to 8-9 $\mathrm{m}$;

$-\sigma=35-50 \mathrm{MPa}$ in the area up to $2.0 \mathrm{~m}$. 
When comparing these data with the value $\sigma_{\text {compr }}$, an obvious conclusion is that all the specified areas of argillite of the immediate bottom are exposed to weakening and destruction.

A coal interlayer, occurring below argillite, although it has a sufficiently high compressive resistance of $\sigma_{\text {compr }}=30.7 \mathrm{MPa}$ even in a water-saturated state, but due to its low thickness $(0.2 \mathrm{~m})$ is extremely unstable to flexure strains and its destruction is also assumed.

Argillite with a low thickness is located below the coal interlayer, and which is probably exposed to moisture saturation with a loss of compressive resistance of $\sigma_{\text {compr }}=3.6 \mathrm{MPa}$. The stresses $\sigma$ acting in it are significantly higher: in the area with a width of up to $10-12 \mathrm{~m}$ and $\sigma=9-15 \mathrm{MPa}$; in the area with a width of up to 6-7 $\mathrm{m}$ and $\sigma=17-30 \mathrm{MPa}$. Therefore, the destruction of an argillite with a low thickness, representing the first layer of the main bottom of the seam $C_{6}$, is quite predictable.

Further on, in depth of a parting, there is a siltstone with medium thickness and a small hardness $\left(\sigma_{\text {compr }}=13.2 \mathrm{MPa}\right)$, even assuming its naturally moist state. The area of increased $\sigma$, exceeding the value $\sigma_{\text {compr }}$, is distributed by the entire siltstone thickness and propagated to the rise of up to 10-12 m. Here, the stresses intensity has a change interval of $\sigma=14-33 \mathrm{MPa}$ and exceeds the compressive resistance up to 2.5 times, contributing to the development of the limiting and superlimiting state in the specified siltstone area.

Below, a thick argillite occurs in a naturally moist state, but is characterized by a small compressive resistance $\sigma_{\text {compr }}=12.9 \mathrm{MPa}$. A behaviour peculiarity of this lithotype is that the middle part of the thickness is exposed to action of $\sigma$, although approaching a value $\sigma_{c o m p r}$, but not exceeding it. That is, part of the argillite thickness maintains stability, but this state, which is close to the limiting one, can be assessed as insufficiently stable under the influence of other weakening factors. In the upper part of the siltstone thickness up to 0.7-0.8 $\mathrm{m}$ high (with a width of up to 8.0-9.0 $\mathrm{m}$ ) and in its lower part up to $2.5-2.7 \mathrm{~m}$ high (with a width of up to $12.0-14.0 \mathrm{~m}$ ) the increased $\sigma=13-18 \mathrm{MPa}$ are acting, which contribute to the weakening of the specified areas. Thus, the most part of the argillite thickness is still in the stage of weakening and it is probable this process development by its entire thickness.

The water-flooded sandstone of medium thickness lying under the argillite has a compressive resistance $\sigma_{\text {compr }}=17.4 \mathrm{MPa}$. In comparison with acting $\sigma=18-25 \mathrm{MPa}$, its weakening should be predicted (by the entire thickness) to a distance of $6.0-7.0 \mathrm{~m}$ to the rise. The rest of the sandstone area in the zone of front bearing pressure is in a stable state.

Argillite is located under the sandstone, which is in an unloaded state for the most part of its thickness. Due to this, even with a very low compressive resistance $\left(\sigma_{c o m p r}=2.7 \mathrm{MPa}\right)$ in a moisture-saturated state, only its upper part with a height of up to $0.6-0.7 \mathrm{~m}$ is predicted to be weakened. The rest of the argillite thickness $(1.9-2.0 \mathrm{~m})$ is stable, as well as the coal seam $C_{5}{ }^{1}$ located below.

In general, the main area of unstable rocks occupies a height of up to $14.6 \mathrm{~m}$ in a parting, which corresponds to $52-55 \%$ of the total parting thickness. Below, only local areas of rocks weakening are located, as well as the zones where lithotypes are in the limiting state or close to it state. Thus, the immediate bottom of the seam $C_{5}{ }^{1}$ is represented by very weak $\left(\sigma_{\text {compr }}=2.7 \mathrm{MPa}\right)$ and low-thickness $(0.6 \mathrm{~m})$ argillite, which is weakened in the area to the rise to a length of 8-11 m. The sandstone of the main bottom of the seam $C_{5}{ }^{1}$, even in a water-flooded state, has a much higher compressive resistance of $\sigma_{\text {compr }}=17.4 \mathrm{MPa}$, and the range of maxima $\sigma$ changes is $14-16 \mathrm{MPa}$. Therefore, this lithotype still maintains continuity, although it is in a state close to the limiting.

Siltstone, located under the sandstone, represents the main roof of the seam $C_{5}+C_{5}{ }^{u}$, for which, due to the significant thickness of $5.2 \mathrm{~m}$, moisture saturation $\left(\sigma_{\text {compr }}=3.2 \mathrm{MPa}\right)$ can be assumed of only its upper bands, adjacent to water-flooded sandstone. Here, the level of acting $\sigma=8-11 \mathrm{MPa}$ weakens the upper siltstone part; the rest of its thickness is in a stable state, since it is characterized by $\sigma_{\text {compr }}=20.2 \mathrm{MPa}$.

The argillite of the immediate roof of the seam $C_{5}+C_{5}{ }^{u}$ is in a naturally moist state with $\sigma_{c o m p r}=12.9 \mathrm{MPa}$, and the value $\sigma$ does not exceed 4-7 MPa. Therefore, a stable state of argillite is predicted.

In the very coal seam $C_{5}+C_{5}{ }^{u}$, the level of stresses intensity is many times lower than its compressive resistance $\sigma_{\text {compr }}=30.1 \mathrm{MPa}$ in the water-flooded state, which indicates its stability.

The argillite of the immediate bottom of the seam $C_{5}+C_{5}{ }^{u}$ is in a water-saturated state with a decrease in a compressive resistance to $\sigma_{c o m p r}=2.7 \mathrm{MPa}$. For this reason, although with a low level of $\sigma$, the local areas still arise of the argillite weakening. These areas are the last ones in depth of the massif, where its discontinuity is predicted, and they are caused not by the influence of the frontal bearing pressure zone in the course of the protecting pillar mining of the seam $C_{6}$, but by the factor of soaking the argillite, which represents the bottom of the seam $C_{5}+C_{5}{ }^{u}$.

As for the influence of the frontal bearing pressure zone, it ends in a thick siltstone of the main roof of the seam $C_{5}+C_{5}{ }^{u}$ at a distance (in height) not less than $4.0-4.5 \mathrm{~m}$ from the arch of the SVC No. 1 contour. From this mark and further in depth of the coal-bearing stratum, its state is close (according to the factor of $\sigma$ action) to the virgin massif behaviour. For this reason, we believe that the stope works along the seam $C_{6}$ do not influence on the SSS of the massif surrounding the SVC No. 1 of the seam $C_{5}$, and the parameters of the stresses components distribution around it will correspond to the peculiarities when maintaining a single mine working.

The practical significance of the performed research is to prove the absence of the overworking influence along the seam $C_{6}$ on the state of the underlying mine working conducted in the bottom of the seam $C_{5}+C_{5}{ }^{u}$. Mine instrumental observations have verified a completely satisfactory state of the SVC No. 1 of the seam $C_{5}$ : the residual area of mine working cross section is more than by 1.5 times exceeds the minimum permissible value according to the ventilation conditions; the rocks convergence parameters of the roof and bottom, crosscut sides do not violate the safety rules for permissible gaps and distances in people movement and the underground transport operation (Fig. 5).

At the same time, mining of the protecting pillar reserves of the seam $C_{6}$ allows output of 157 thousand tons of coal without any significant additional costs for maintaining the SVC No. 1 of the seam $C_{5}$. 


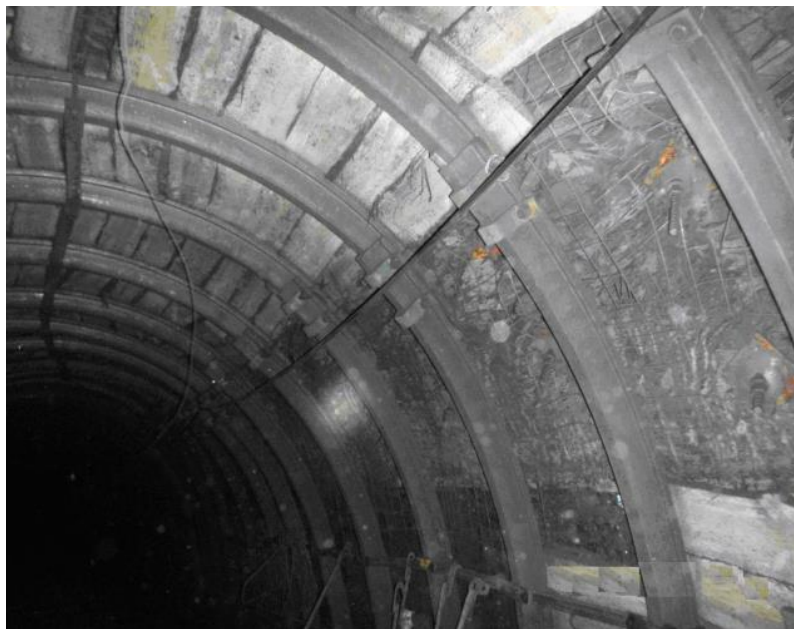

Figure 5. The steep-dipping ventilation crosscut state

\section{Conclusions}

The studies of mining-geological and engineering conditions of overworking the SVC No. 1 of the seam $C_{5}$ have revealed:

- analysis of the composition and properties of the coalbearing stratum, including the roof of the seam $C_{6}$, parting and bottom of the seam $C_{5}+C_{5}{ }^{u}$ has led to a well-founded conclusion about the necessity of a computational experiment to calculate the SSS of a geomechanical model with vast dimensions: about $70 \mathrm{~m}$ high, $25 \mathrm{~m}$ along the strike, $150 \mathrm{~m}$ to the rise-dip;

- the adequacy and reliability of the SSS calculation results of the geomechanical model are conditioned by: a reflection of the real massif structure; strength and deformation properties of rock layers have been chosen with account of the influence of factors weakening the rock, namely, stratification, fracturing and moisture saturation from adjacent water-flooded lithotypes; a criterion for contacts discontinuity of adjacent lithotypes, the most characteristic for the Western Donbas conditions, has been introduced; a longwall face with a powered support simulator has been modelled along the seam $C_{6}$, which fully reflects the real deformation-strength characteristic of the sections of stope complex; behind the longwall face in the seam $C_{6}$ roof, all characteristic zones are constructed - uncontrolled collapse, hinged-block displacement, smooth deflection of the layers without discontinuity;

- throughout the height of a parting, three areas of lithotypes discontinuity have been identified; at the same time, it has been found that the underlying rock layers with a total thickness of $19.0 \mathrm{~m}$, enclosing the SVC No. 1 of the seam $C_{5}$, do not experience the overworking influence along the seam $C_{6}$ and are in the initial geostatic state of the virgin massif;

- the SVC No. 1 of the seam $C_{5}$ is in a completely satisfactory operational state (according to the results of mine instrumental observations), which will not be disturbed when mining the overlying protecting pillar of the seam $C_{6}$.

\section{Acknowledgements}

The authors express their gratitude to the management of DTEK Coal Unit for their help in organizing the experimental research.

\section{References}

[1] Bondarenko, V., Kovalevs'ka, I., \& Ganushevych, K. (2014). Progressive technologies of coal, coalbed methane, and ores mining. London, United Kingdom: CRC Press, Taylor \& Francis Group. https://doi.org/10.1201/b17547

[2] Sheorey, P., Loui, J., Singh, K., \& Singh, S. (2000). Ground subsidence observations and a modified influence function method for complete subsidence prediction. International Journal of Rock Mechanics and Mining Sciences, 37(5), 801-818. https://doi.org/10.1016/s13651609(00)00023-X

[3] Liu, T. (1995). Influence of mining activities on mine rockmass and control engineering. Journal - China Coal Society, 20(1), 1-5.

[4] Piwniak, G.G., Bondarenko, V.I., Salli, V.I., Pavlenko, I.I., \& Dychkovskiy, R.O. (2007). Limits to economic viability of extraction of thin coal seams in Ukraine. Technical, Technological and Economic Aspects of Thin-Seams Coal Mining, International Mining Forum, 129-132. https://doi.org/10.1201/noe0415436700.ch16

[5] Hou, J., Li, G., Hu, N., \& Wang, H. (2019). Simultaneous integrated optimization for underground mine planning: Application and risk analysis of geological uncertainty in a gold deposit. Gospodarka $\begin{array}{lll}\text { Surowcami } & \text { Mineralnymi, } & \text { 35(2), }\end{array}$ https://doi.org/10.24425/gsm.2019.128518

[6] Kalybekov, T., Rysbekov, K.B., Toktarov, A.A., \& Otarbaev, O.M. (2019). Underground mine planning with regard to preparedness of mineral reserves. Mining Informational and Analytical Bulletin, (5), 34-43.

[7] Villalba M.M.E., \& Kumral, M. (2018). Underground mine planning: stope layout optimisation under grade uncertainty using genetic algorithms. International Journal of Mining, Reclamation and Environment, 33(5), 353-370. https://doi.org/10.1080/17480930.2018.1486692

[8] Pivnyak, G., Bondarenko, V., Kovalevs'ka, I., \& Illiashov, M. (2012). Geomechanical processes during underground mining. London, United Kingdom: CRC Press, Taylor \& Francis Group. https://doi.org/10.1201/b13157

[9] Bondarenko, V., Symanovych, H., Kicki, J., Barabash, M., \& Salieiev, I. (2019). The influence of rigidity of the collapsed roof rocks in the mined-out space on the state of the preparatory mine workings. Mining of Mineral Deposits, 13(2), 27-33. https://doi.org/10.33271/mining 13.02.027

[10] Bondarenko, V., Kovalevska, I., Symanovych, H., Barabash, M., \& Snihur, V. (2018). Assessment of parting rock weak zones under the joint and downward mining of coal seams. E3S Web of Conferences, (66), 03001. https://doi.org/10.1051/e3sconf/20186603001

[11] Walentek, A., Janoszek, T., Prusek, S., \& Wrana, A. (2019). Influence of longwall gateroad convergence on the process of mine ventilation network model tests. International Journal of Mining Science and Technology, 29(4), 585-590. https://doi.org/10.1016/j.ijmst.2019.06.013

[12] Prusek, S., Rajwa, S., Wrana, A., \& Krzemień, A. (2017). Assessment of roof fall risk in longwall coal mines. International Journal of Mining, Reclamation and Environment, 31(8), 558-574. https://doi.org/10.1080/17480930.2016.1200897

[13] Yuan, Y., Chen, Z., Xu, C., Zhang, X., \& Wei, H. (2018). Permeability enhancement performance and its control factors by auger mining of extremely thin coal seams. Journal of Geophysics and Engineering, 15(6), 2626-2641. https://doi.org/10.1088/1742-2140/aae068

[14] Yang, D., Li, J., Wang, Y., \& Jiang, H. (2017). Research on vibration and deflection for drilling tools of coal auger. Journal of Vibroengineering, 19(7), 4882-4897. https://doi.org/10.21595/jve.2017.18581

[15] Follington, C., Deeter, I.L., Share, R., \& Moolman, D. (2001). A new underground auger mining system. Journal of the Southern African Institute of Mining and Metallurgy, 101(1), 25-32.

[16] Li, J.G., \& Zhan, K. (2018). Intelligent mining technology for an underground metal mine based on unmanned equipment. Engineering, 4(3), 381-391. https://doi.org/10.1016/j.eng.2018.05.013

[17] Fan, Q., Li, W., Hui, J., Wu, L., Yu, Z., Yan, W., \& Zhou, L. (2014). Integrated positioning for coal mining machinery in enclosed underground mine based on SINS/WSN. The Scientific World Journal, (2014), 1-12. https://doi.org/10.1155/2014/460415

[18] Malkowski, P., \& Ostrowski, L. (2019). Convergence monitoring as a basis for numerical analysis of changes of rock-mass quality and Hoek-Brown failure criterion parameters due to longwall excavation. Archives of Mining Sciences, 64(1), 93-118. https://doi.org/10.24425/ams.2019.126274

[19] Bulat, A.F., Voloshyn, O.I., Potapchuk, I.Y., Yemelianenko, V.I., Zhovtonoha, M.M., Zhevzhyk, O.V., Manigandan, S. (2019). Mathematical modeling of the gas dynamic parameters of impinging heattransfer medium jet in borehole thermal reaming process. Science and Innovation, 15(3), 17-23. https://doi.org/10.15407/scine15.03.017 
[20] Sdvizhkova, Ye.A., Babets, D.V., \& Smirnov, A.V. (2014). Support loading of assembly chamber in terms of Western Donbas plough longwall. Naukovyi Visnyk Natsionalnoho Hirnychoho Universytetu, (5), 26-32.

[21] Malanchuk, Z.R., Moshynskyi, V.S., Korniienko, V.Y., Malanchuk, Y.Z., \& Lozynskyi, V.H. (2019). Substantiating parameters of zeolite-smectite puff-stone washout and migration within an extraction chamber. Naukovyi Visnyk Natsionalnoho Hirnychoho Universytetu, (6), 11-18. https://doi.org/10.29202/nvngu/2019-6/2

[22] Bondarenko, V., Symanovych, G., \& Koval, O. (2012). The mechanism of over-coal thin-layered massif deformation of weak rocks in a longwall. Geomechanical Processes during Underground Mining Proceedings of the School of Underground Mining, 41-44. https://doi.org/10.1201/b13157-8

[23] Sotskov, V., \& Saleev, I. (2013). Investigation of the rock massif stress strain state in conditions of the drainage drift overworking. Annual Scientific-Technical Collection - Mining of Mineral Deposits, 197-201. https://doi.org/10.1201/b16354-36

[24] Bondarenko, V.I., Kharin, Ye.N., Antoshchenko, N.I., \& Gasyuk, R.L. (2013). Basic scientific positions of forecast of the dynamics of methane release when mining the gas bearing coal seams. Naukovyi Visnyk Natsionalnoho Hirnychoho Universytetu, (5), 24-30.

[25] Khomenko, O.Ye. (2012). Implementation of energy method in study of zonal disintegration of rocks. Naukovyi Visnyk Natsionalnoho Hirnychoho Universytetu, (4), 44-54.

[26] Khalymendyk, I., \& Baryshnikov, A. (2018). The mechanism of roadway deformation in conditions of laminated rocks. Journal of Sustainable Mining, 17(2), 41-47. https://doi.org/10.1016/j.jsm.2018.03.004

[27] Barabash, M.V. (2017). Intensyfikatsiia hirnychykh robit pry sumisnoти vidpratsiuvanni vuhil'nykh plastiv $z$ urakhuvanniam zon znemitsnennia mizhplastia. PhD Thesis. Dnipro, Ukraine: NGU.

[28] Bondarenko, V., Kovalevska, I., Husiev, O., Snihur, V., \& Salieiev, I. (2019). Concept of workings reuse with application of resource-saving bolting systems. E3S Web of Conferences, (133), 02001. https://doi.org/10.1051/e3sconf/201913302001

[29] Bondarenko, V., Kovalevska, I., Symanovych, G., Sotskov, V., \& Barabash, M. (2018). Geomechanics of interference between the operation modes of mine working support elements at their loading. Mining Science, (25), 219-235. https://doi.org/10.5277/msc182515

[30] Usachenko, B.M. (1979). Svoystva porod i ustoychovost' gornykh vyrabotok. Kyiv, Ukraina: Naukova dumka.
[31] Usachenko, B.M., Kirichenko, V.Ya., \& Shmigol', A.V. (1992). Okhrana podgotovitel'nykh vyrabotok glubokikh gorizontov shakht Zapadnogo Donbassa. Moskva, Rossiya.

[32] Usachenko, B.M., Cherednichenko, V.P., \& Golovchanskiy, I.Ye (1990). Geomekhanika okhrany vyrabotok $v$ slabometamorfizirovannykh porodakh. Kyiv, Ukraina: Naukova dumka.

[33] Zborshchik, M.P., \& Nazimko, V.V. (1991). Okhrana vyrabotok glubokikh shakht $v$ zone razgruzki. Kyiv, Ukraina: Tekhnika.

[34] Kovalevska, I., Pilecki, Z., Husiev, O., \& Snihur, V. (2019). Assessment of the mutual influence of deformation-strength characteristics of the fastening system elements. E3S Web of Conferences, (123), 01006. https://doi.org/10.1051/e3sconf/201912301006

[35] Kovalevska, I., Symanovych, G., \& Fomychov, V. (2013). Research of stress-strain state of cracked coal-containing massif near the working area using finite elements technique. Annual Scientific-Technical Collection - Mining of Mineral Deposits, 159-163. https://doi.org/10.1201/b16354-28

[36] Lozynskyi, V., Saik, P., Petlovanyi, M., Sai, K., \& Malanchuk, Ye. (2018). Analytical research of the stress-deformed state in the rock massif around faulting. International Journal of Engineering Research in Africa, (35), 77-88. https://doi.org/10.4028/www.scientific.net/JERA.35.77

[37] Pisarenko, G.S. (1979). Soprotivlenie vaterialov. Kyiv, Ukraina: Vyshcha shkola.

[38] Bondarenko, V., Kovalevs'ka, I., Svystun, R., \& Cherednichenko, Y. (2013). Optimal parameters of wall bolts computation in the united bearing system of extraction workings frame-bolt support. Аnпиаl Scientific-Technical Collection - Mining of Mineral Deposits 2013, 5-9. https://doi.org/10.1201/b16354-3

[39] Anur'ev, V.I. (1980). Spravochnik konstruktora-mashinostroitelya. Moskva, Rossiya: Mashinostroenie.

[40] Kyrychenko, Y., Samusia, V., \& Kyrychenko, V. (2012). Software development for the automatic control system of deep-water hydrohoist. Geomechanical Processes during Underground Mining Proceedings of the School of Underground Mining, 81-86. https://doi.org/10.1201/b13157-14

[41] Baklashov, I.V. (1988). Deformirovanie i razrushenie porodnykh massivov. Moskva, Rossiya: Nedra.

[42] Bulychev, N.S. (1982). Mekhanika podzemnykh sooruzheniy. Moskva, Rossiya: Nedra.

\section{Стійкість надроблюваного слабометаморфізованого масиву навколо гірничої виробки}

\section{І. Ковалевська, В. Самуся, Д. Колосов, В. Снігур, Т. Письменкова}

Мета. Дослідити механізми стійкості надроблюваного слабометаморфізованого масиву навколо гірничої виробки на прикладі шаруватих порід Західного Донбасу (Україна).

Методика. Аналіз впливу надробки при плануванні гірничих робіт на нижніх горизонтах виконано 3 урахуванням досліджень напружено-деформованого стану на верхніх горизонтах. Приділено увагу умовам слабометаморфізованого вуглепородного масиву, який має специфічні механічні властивості та особливості будови. Проведено обчислювальний експеримент методом скінченних елементів. Доведено адекватність моделі і достовірність розрахунку напружено-деформованого стану. Результати досліджень підтверджено шахтним експериментом.

Результати. Обгрунтовано геомеханічну модель обчислювального експерименту, в якому відображено реальну текстуру масиву, фактори шаруватості, тріщинуватості і вологонасичення, які послаблюють міцнісні й деформаційні властивості порід. Досліджено зони безладного обвалення, шарнірно-блокового зсуву, плавного прогину шарів без порушення суцільності.

Наукова новизна. Встановлено закономірності впливу надробки на стан виробок у шаруватому масиві слабких порід. При цьому виявлено три зони порушення цілісності літотипів по висоті міжпластя і проаналізовано параметри компонент напружень $і$ їх відповідність реальним гірничо-геологічним умовам.

Практична значимість. Доведено відсутність впливу надробки на стан нижніх виробок у слабометаморфізованому масиві. Проведено порівняльний аналіз із результатами шахтного експерименту. Показано можливість відпрацювання запасів охоронного цілика, що дозволить видобути додаткове вугілля без залучення суттєвих матеріальних засобів.

Ключові слова: гірський масив, геомеханічні фактори, надробка, напружено-деформований стан, кріплення

\section{Устойчивость надрабатываемого слабометаморфизированного массива вокруг горной выработки}

\section{И. Ковалевская, В. Самуся, Д. Колосов, В. Снигур, Т. Письменкова}

Цель. Исследовать механизмы устойчивости надрабатываемого слабометаморфизированного массива вокруг горной выработки на примере слоистых пород Западного Донбасса (Украина).

Методика. Анализ влияния надработки при планировании горных работ на нижележащих горизонтах выполнен с учетом исследований напряженно-деформированного состояния на вышележащих горизонтах. Уделено внимание условиям слабометаморфизированного углепородного массива, который имеет специфические механические свойства и особенности строения. Проведен вычислительный эксперимент методом конечных элементов. Доказаны адекватность модели и достоверность расчета напряженно-деформированного состояния. Результаты исследований подтверждены шахтным экспериментом. 
Результаты. Обоснована геомеханическая модель вычислительного эксперимента, в которой отражена реальная текстура массива, ослабляющие прочностные и деформационные свойства пород факторы слоистости, трещиноватости и влагонасыщения. Исследованы зоны беспорядочного обрушения, шарнирно-блокового сдвижения, плавного прогиба слоев без нарушения сплошности.

Научная новизна. Установлены закономерности влияния надработки на состояние выработок в слоистом массиве слабых пород. При этом выявлены три области нарушения целостности литотипов по высоте междупластья и проанализированы параметры компонент напряжений и их соответствие реальным горно-геологическим условиям.

Практическая значимость. Доказано отсутствие влияния надработки на состояния нижележащих выработок в слабометаморфизированном массиве. Проведен сравнительный анализ с результатами шахтного эксперимента. Показана возможность отработки запасов охранного целика, что позволит добыть дополнительный уголь без привлечения существенных материальных средств.

Ключевые слова: горный массив, геомеханические факторы, надработка, напряженно-деформированное состояние, крепь

\section{Article info}

Received: 14 September 2019

Accepted: 6 April 2020

Available online: 18 April 2020 